\title{
Extended Use of Limestone Fines in Various Concretes
}

\author{
Gilson R. Lomboy ${ }^{1}$, Fatih Bektas ${ }^{1,2}$ and Kejin Wang ${ }^{1}$ \\ 1. Department of Civil, Construction and Environmental Engineering, Iowa State University, Ames, IA 50011, USA \\ 2. Institute for Transportation, Iowa State University, Ames, IA 50010, USA
}

\begin{abstract}
Limestone fines are increasingly used in cement and concrete for improved material properties and sustainability. This paper presents recent research at Iowa State University on utilization of limestone fines in concrete. It includes the beneficial uses of limestone fines in: (1) limestone blended Portland cement; (2) SFSCC (semi-flowable self-consolidating concrete); and (3) HPC (high performance concrete). The research results show that using $5 \% \sim 10 \%$ of limestone fines to replace for Type IP cement (with $25 \%$ fly ash) increased mortar strength. Well-designed SFSCC with $25 \%$ limestone fines (by mass of cementitious materials) displayed desirable rheological and mechanical properties required for slip-forming construction. The newly developed limestone fines-based $\mathrm{HPC}$ reached the one-day compressive strength of over $28 \mathrm{MPa}$.
\end{abstract}

Key words: Limestone fines, semi-flowable self-consolidating concrete, high performance concrete.

\section{Introduction}

The US domestic production of industrial limestone is about 1.3 billion metric tons, 413 million tons of which is used for construction. In the limestone used for construction, approximately 50 million tons (12\%) are fines $(<9.5 \mathrm{~mm}$ or $3 / 8$ inch), most commonly used as backfilling materials, with a very low value, because they often do not meet concrete aggregate gradation requirements [1]. Limestone fines have been historically used as an inert filler in concrete mixtures [2]. They were commonly used to replace Portland cement in concrete when Portland cement was used in high amounts, such as in self-consolidating concrete where the fine materials was used for increasing the viscosity of the concrete and prevent segregation [3].

In recent years, it was realized that limestone fines not only act as a filler [4, 5], but also aid in the hydration process of Portland cement when supplied as very fine particles. This is by accelerating the hydration through nucleation and creation of new types of hydration products, such as calcium carboaluminate [6-14]. From the accelerated hydration due to

Corresponding author: Kejin Wang, Ph.D., professor, research fields: concrete chemistry and microstructure, workability and rheology, durability and sustainability. nucleation, it has been observed that it modifies the calcium-to-silica ratio of C-S-H (calcium-silicahydrate) [15]. A more disoriented crystallization of $\mathrm{CH}$ (calcium hydroxide) has also been suggested due to heterogeneous nucleation, when limestone particles act as nucleation sites [16]. Limestone is not known to exhibit pozzolanic properties, and consequently does not produce C-S-H gel [17].

Most specifications on Portland cement composition permits the incorporation of less than 5\% limestone to Portland cement [18-20]. In the survey conducted by the Portland Cement Association [21], it was concluded that in general, the use of up to $5 \%$ limestone does not affect the performance of Portland cement, and that higher amounts may be possible for low water-to-cement ratio's $(<0.45)$ systems where a substantial fraction of the cement particles remain unhydrated, effectively acting as fillers [22-24]. PLC (Portland limestone cement) has been added as a new type of cementitious material in some standards, e.g., European Standard (BS EN 197-1:2011) and Canadian Standard (CAN/CSA-A23.1-09/A23.2-09). PLC can contain higher amounts of limestone (up to $35 \%$ ), but limestone and Portland cement clinker may have to be interground to a finer powder to achieve similar results 
to general use Portland cement.

Research is also being conducted on effects on durability of mixtures with limestone fines used as filler. In Isassar's [25] review on sulfate resistance of cementitious materials with limestone filler, he gathered that there was no significant changes in sulfate resistance with low amounts of limestone fines (less than $10 \%$ of cementitious) and permeability and water-to-binder ratio were key parameters in their resistance. However, limestone fines greater than $15 \%$ may deteriorate sulfate performance. With sulfate attack, thaumasite may form due to the presence of calcium silicate ions (from C-S-H and/or ettringite) and carbonate ions (from limestone fines), converting main phases of hydrated cement paste to a non-binder thaumasite [26-28]. Observations showed that deterioration was highly dependent on $w / c$ (water-to-cement) ratio and $\mathrm{C}_{3} \mathrm{~A}$ (tricalcium aluminate) content of the cement. Surface damage was controlled when low effective $w / c$ ratio and low $\mathrm{C}_{3} \mathrm{~A}$ were used.

In the present study, investigations on the potential use of limestone fines are focused on: (1) limestone blended Portland cement; (2) SFSCC (limestone fine modified semi-flowable self-consolidating concrete); and (3) limestone-based HPC (high performance concrete). The research results are presented in the following.

\section{Limestone Blended Portland Cement-Effects on Hydration and Strength}

There are two methods by which limestone fines are incorporated into cementitious systems. The first is by addition, whereby limestone fines are to replace a percentage of cementitious materials or as filler, which are added during the mixing process. The other method is by co-grinding with Portland cement clinker, making the limestone a component of Portland cement.

With the addition of limestone fines, Poppe and Schutter [29] found that on isothermal and adiabatic hydration tests on self-compacting and traditional concrete, the reaction mechanism of the Portland cement is clearly influenced by the addition of the limestone filler. The induction period is shortened and an extra heat production peak sometimes occurs, even at the lowest testing temperatures. The higher the amount of filler and the higher the testing temperature, the more pronounced the peak is. Bentz [30] studied the effect of adding limestone fines by computer simulation. Both the chemical and fine filler effects of limestone on cement hydration were addressed. Predictions were in good agreement with experimental results on the acceleration of cement hydration only in lower $w / s$ (water-to-solids) (e.g., 0.35) ratio blended cement pastes. In these systems, up to $20 \%$ of the cement could potentially be substituted by limestone (or other fillers) to economize on the usage of Portland cement clinker and to reduce the energy and the deleterious emissions associated with its production.

PLC is manufactured by co-grinding with clinker. In such systems, the resulting limestone fines tend to be finer than those added during the concrete mixing process, to provide the same 28-day compressive strength to Portland cement without limestone fines.

Voglis et al. [31] compared the behavior of cementitious systems with the same 28-day compressive strength and containing supplementary materials - limestone, natural pozzolana or fly ash. The supplementary materials were co-grounded with clinker. The co-grinding process affects the fineness of the clinker and therefore the properties of the cements; cements with fly ash were coarser than cement with limestone. The cement containing limestone had higher early strength, while cements with natural pozzolana or fly ash exhibit significantly higher compressive strength at 90 days and up to 540 days. Tsivilis et al. [32] studied the parameters affecting the properties of PLC. They found that clinker with higher $\mathrm{C}_{3} \mathrm{~A}$ is more reactive with limestone due to the formation of carboaluminates, but dolomitic limestone performs better with clinker with lower $\mathrm{C}_{3} \mathrm{~A}$. The effect of fineness on the clinker reactivity and strength development varies in relation to clinker and limestone 
composition.

The US specifications (i.e., ASTM C150) currently allow only up to $5 \%$ ground limestone, while Canada permits up to $15 \%$ ground limestone as a replacement for Portland cement. On the other hand, Europe has been using ground limestone at much higher levels for over 25 years: Europe's PLC, CEM II/A-L and CEM II/B-L, contain $6 \%$ to $20 \%$ and $21 \%$ to $35 \%$ ground limestone, respectively. Around $20 \%$ of all cement sold in Europe contains between 6\% and 35\% limestone. Based on 2004 data PLC has the largest share in production (Fig. 1).
The first study presented here aimed to evaluate the effect of limestone fines as a Portland cement blend component for Types I and IP (25\% fly ash) cements, particularly, its effects on strength and air permeability. The cements were replaced by limestone fines in mortar mixtures up to $20 \%$ and in concrete up to $10 \%$. The limestone used in the study is the fine residue of a local aggregate manufacturing plant (i.e., industrial waste). It was further ground in a laboratory type ball mill so that the $45-\mu \mathrm{m}$ sieve residue was $13.9 \%$.

Figs. 2 and 3 show the compressive strength at different ages of mortar samples with Types I and IP

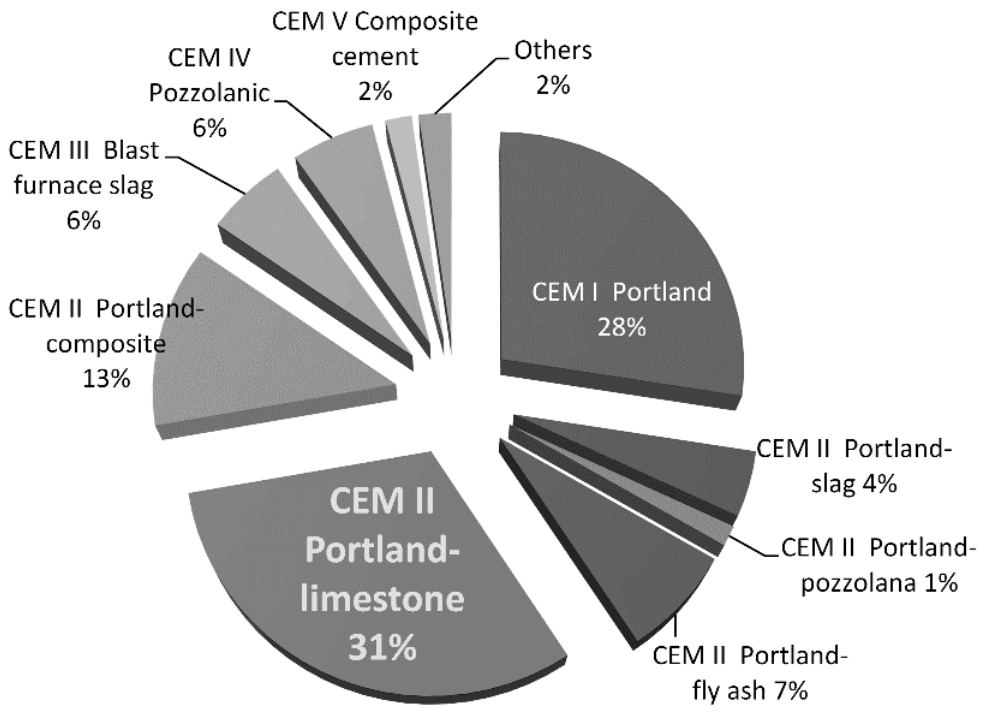

Fig. 1 Types of cement produced in Europe [33].

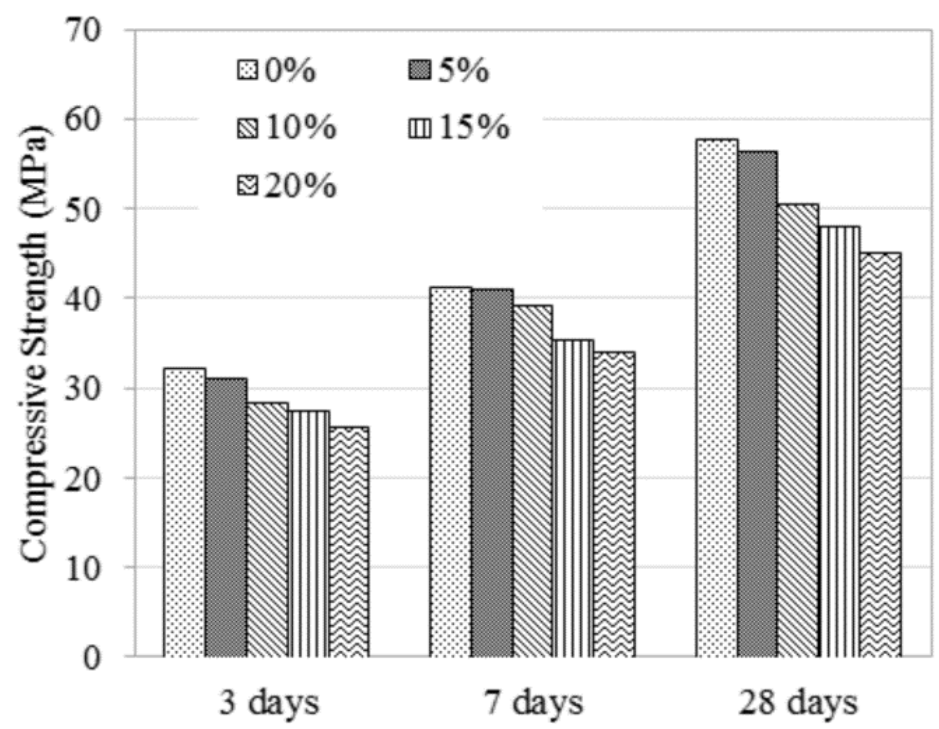

Fig. 2 Type I cement with limestone fines mortar compressive strength. 


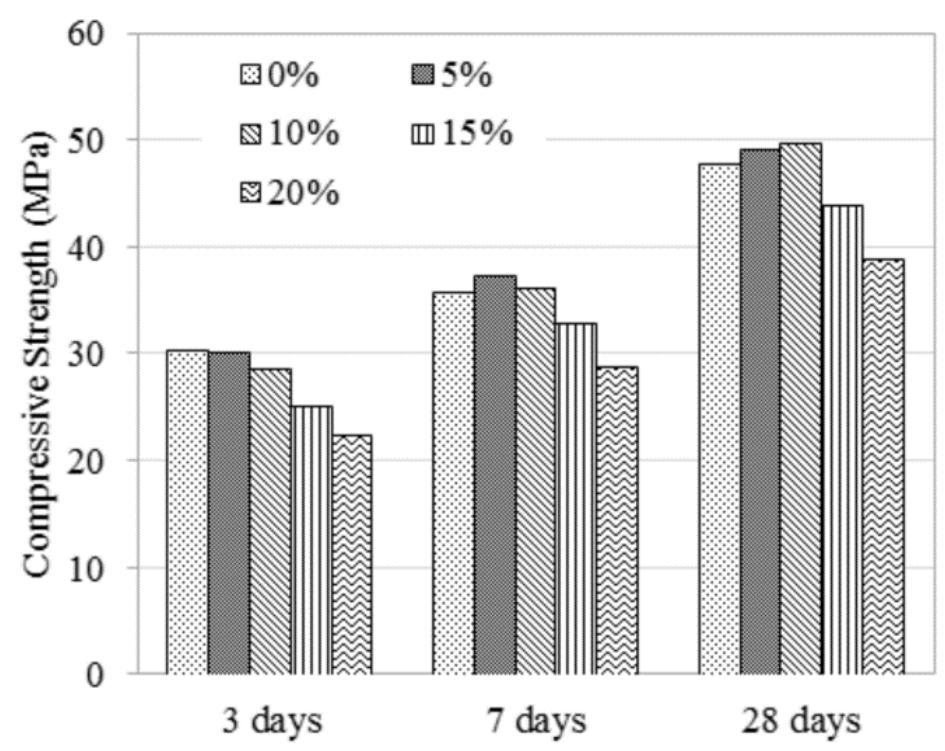

Fig. 3 Type IP cement with limestone fines mortar compressive strength.

cements with increasing limestone fines replacement, respectively. For the case of Type I cement in Fig. 2, increasing the amount of limestone fines decreases the strength of mortars. It could be noted that the size of the limestone fines for both types of cements are the same. For Type I cement, there was no benefit found in terms of compressive strength with addition of limestone fines. A finer limestone may be necessary to maintain or improve the compressive strength in Type I cement. However, for the case of Type IP cement, beneficial increase in compressive strength is found in the range of 5\% to $10 \%$ replacement as shown in Fig. 3. In the study conducted by Voglis et al. [31] on co-grinding of clinker with fly ash and limestone, it was found that the resulting particles were coarser than clinker with limestone only. In the present study, the size of the limestone particles may be complementary in combination with Type IP to improve packing when acting as a filler, and subsequently improving compressive strength. As mentioned previously, limestone fines can also react with fly ash to produce calcium carboaluminate, which may also help improve the mortar strength.

In Fig. 4, the air permeability index of concrete made with Types I and IP with limestone fines at 56 days are shown. The permeability index is taken as the $-\log 10$ of the D'arcy coefficient of permeability. Although the permeability index of Type IP with limestone fines may be slightly lower than Type I with limestone fines, either due to packing pozzolanic reaction, and/or fly ash-limestone fine reaction, the difference in the results are not significant.

\section{Limestone Fine Modified Semi-flowable Self-consolidating Concrete-Effects on Rheology}

SCC (conventional self-consolidating concrete) is a highly flowable mixture that achieves full consolidation without the application of mechanical vibration. SFSCC has a much less flowability than SCC, but also consolidates without the application of mechanical vibration and has the advantage of possessing green strength and shape stability. SFSCC was developed to address the issue of concrete being able to consolidate under its own weight and retain its shape after being extruded from its form while in its fresh state. Similar to SCC, SFSCC has the benefit of increased productivity and work safety and reduction in construction noise [34, 35].

Fig. 5 shows compositions of various SFSCC mixtures and one conventional slip-form concrete pavement mixture labeled C-3WR-C20. SFSCC-LD is 


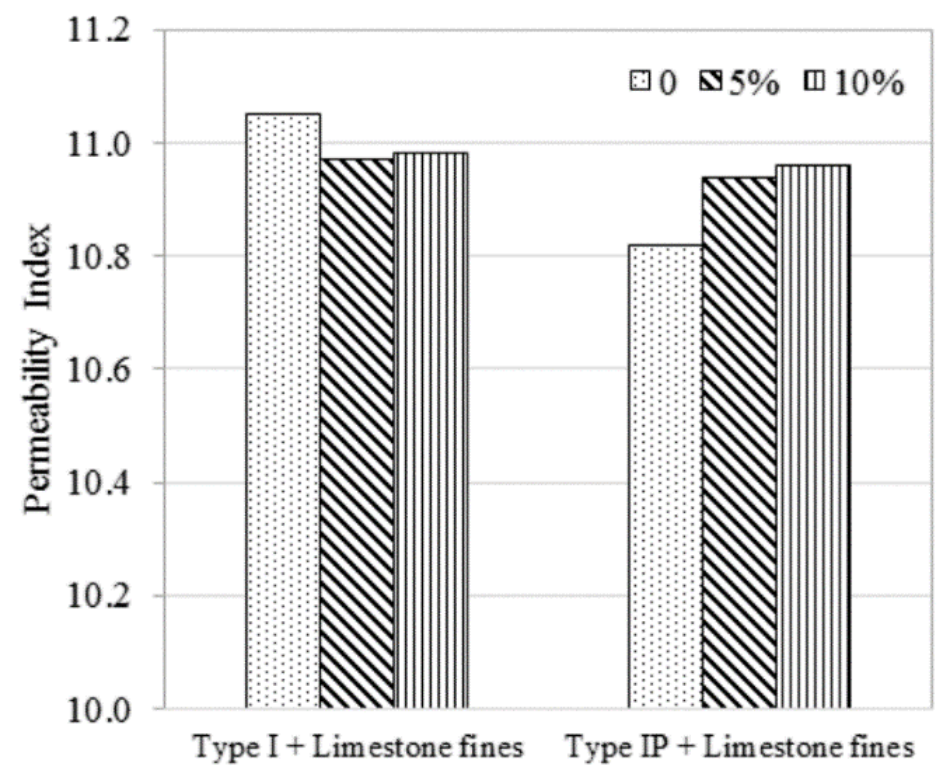

Fig. 4 Permeability of concrete with Type I or Type IP with limestone fines.

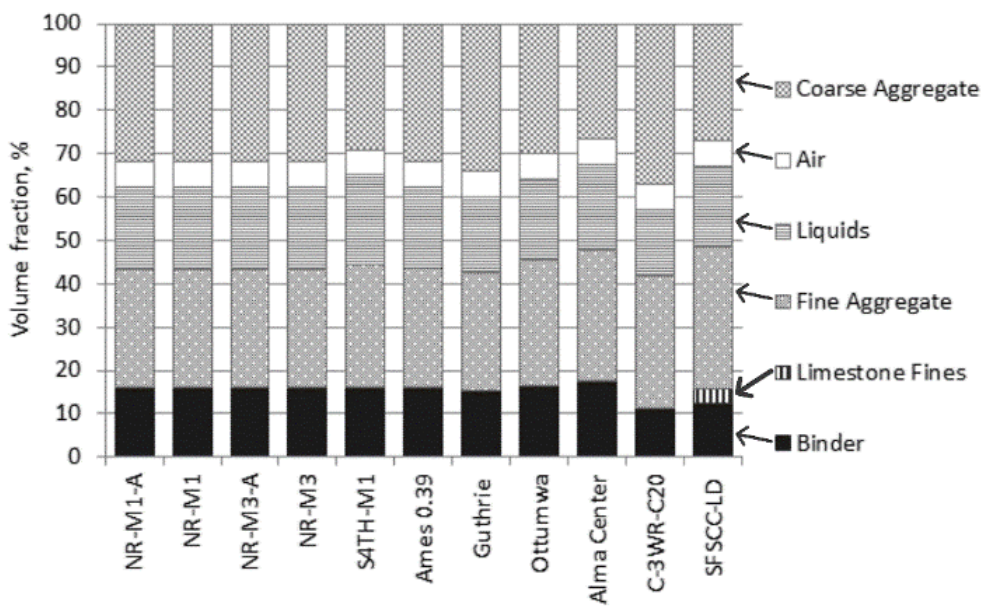

Fig. 5 Typical compositions of concrete mixtures (C-3WR-C20 is a very low slump slip-form pavement mixture. Other mixtures are semi-flowable self-consolicating concrete that are applicable for slip-form construction. SFSCC-LD is an SFSCC mixture with limestone fines).

an SFSCC mixture that had limestone fines incorporated. Limestone fines were added into the SFSCC-LD mixture to reduce the amount of cement while maintaining the volume of fine materials. The mix proportion of the SFSCC containing limestone fines was developed in the combined consideration of concrete rheology, strength and durability [36].

The flow curves of SFSCC and conventional pavement concrete (C-3WR-C20) were measured to compare their rheological properties. The flow curve here represents the amount of torque or stress that the fresh concrete needs for it to flow at a given shearing rate. For concrete, the flow curves were developed using an IBB rheometer [37]. The flow curves for concrete are shown in Fig. 6. Two types of concrete were explicitly labeled, C-3WR-C20 and SFSCC-LD. Other curves are for other types of SFSCC [37]. It can be observed that SFSCC-LD has similar viscosity to other types of SFSCC. Viscosity is represented by the slope of the flow curve. The torque value when the flow curve is extended to a speed of zero represents the minimum required effort to maintain concrete flow. 


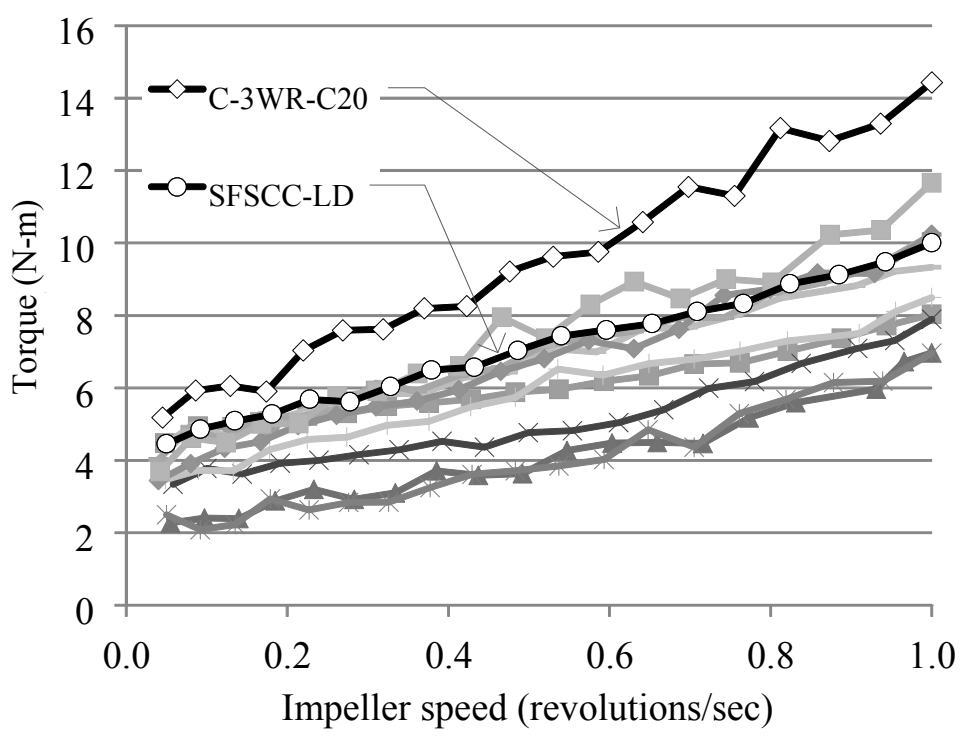

Fig. 6 IBB rheometer torque vs. impeller speed for SFSCC and conventional pavement concrete (C-3WR-C20) [38].

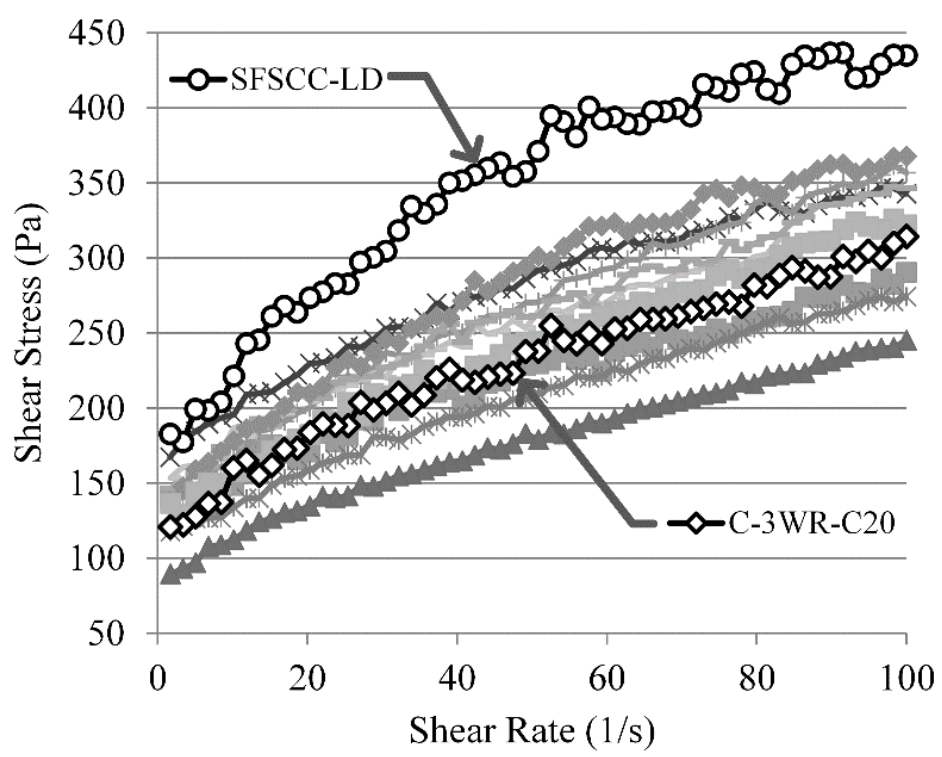

Fig. 7 Flow curves of mortar that were sieved from SFSCC and conventional pavement concrete [38].

For SFSCC-LD, this torque value is at the upper range of the SFSCC mixtures. When compared with conventional pavement concrete, it can be seen that SFSCC-LD has a slightly lower minimum torque, while it has a much lower viscosity. This is mainly attributed to the greater amount of coarse aggregates in C-3WR-C20, as shown in Fig. 5. The lesser minimum torque and viscosity has been shown to be sufficient for SFSCC to obtain self-consolidation $(\geq 98 \%$ consolidation relative to mechanically vibrated concrete) and maintain a stable shape after extrusion from a paver [38].

The flow curves of the mortar component of the concrete mixtures presented in Fig. 6 were also tested, using a Brookfield rheometer. Mortars were extracted from concrete by sieving, and then were tested. The flow curves for the mortars are shown in Fig. 7. Highlighted are the results from the SFSCC-LD mortar 
and C-3WR-C20 mortar. Other flow curves shown in Fig. 7 are from other SFSCC mixtures. As clearly shown, the mortar component of SFSCC-LD has a higher viscosity compared to other types of SFSCC mortars, while the C-3WR-C20 mortar component is very similar to most SFSCC mortar component. The yield stress, which is the yield stress at zero shear rate, for SFSCC mortar is also higher than other types of SFSCC and C-3WR-C20. The replacement of Portland cement with limestone fines had contributed to increased viscosity of the mortar component. As a result, when compared with other SFSCC mixtures in Fig. 5, SFSCC-LD required less coarse aggregate to maintain the same concrete rheological properties shown in Fig. 6. Therefore, the low viscosity of SFSCC-LD is due to using a smaller amount of coarse aggregate to complement the use of limestone fines, while the higher viscosity of C-3WR-C20 is due to using a higher amount of coarse aggregate.

The hardened properties and durability of SFSCC-LD are comparable to conventional pavement concrete and other SFSCC mixtures. In terms of compressive strength, the use of limestone fines provides a slightly higher early age compressive strength as shown in Fig. 8, which is typical of concrete with limestone fines as mentioned in the introduction. The compressive strength at 28 days is similar to conventional pavement concrete and close to the average of SFSCC mixtures.

The unrestrained shrinkage of concrete prisms from selected SFSCC mixtures and C-3WR-C20 was also measured. The percent length change with time is shown in Fig. 9. Because limestone fines were used to replace Portland cement, the degree of shrinkage of SFSCC-LD is less compared to other SFSCCs. Compared to C-3WR-C20, SFSCC tends to have greater length change due to higher Portland cement content.

SFSCC-LD is durable when subjected to cyclic F-T (freezing-thawing). The different types of concrete were subjected to $300 \mathrm{~F}-\mathrm{T}$ cycles and the decrease in RDM (relative dynamic modulus) due to F-T damage was recorded, as shown in Fig. 10. It is interesting to note that instead of a gradual decrease in RDM with increasing F-T cycles or a rapid decrease of RDM toward the high number of F-T cycles due to accumulation of damage, SFSCC-LD first has an abrupt decrease in RDM and then maintains its integrity with continued F-T cycles. The use of limestone fines may have altered the degradation process which needs further investigation.

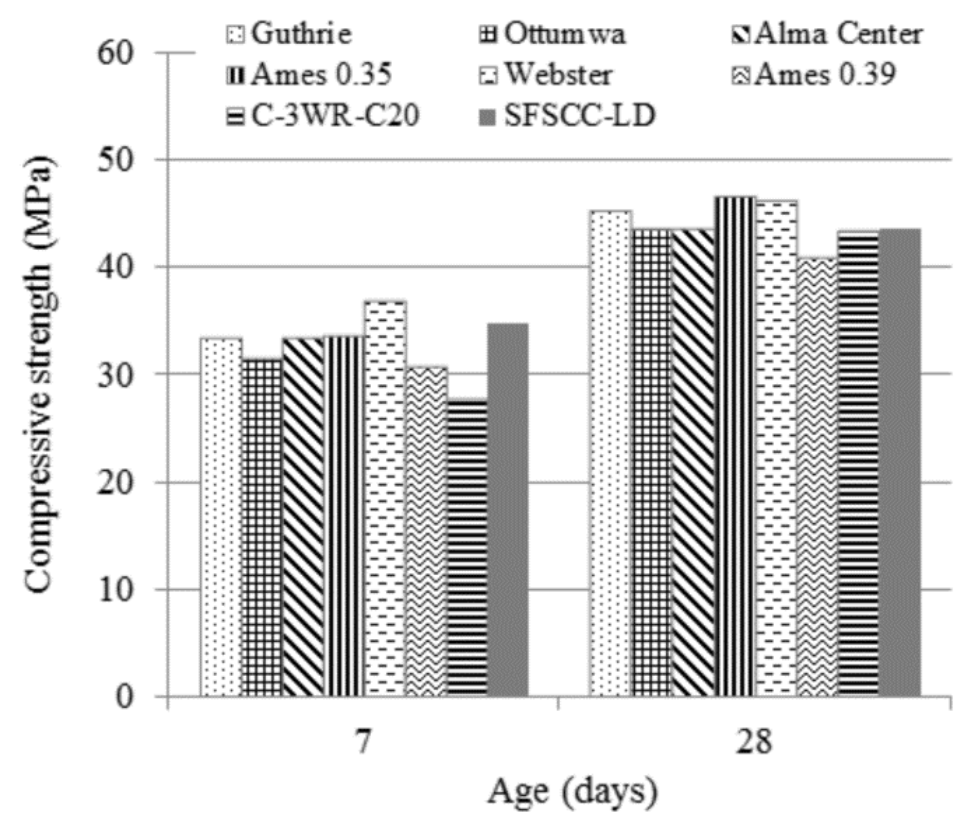

Fig. 8 Compressive strength of SFSCC and conventional pavement concrete at 7 days and 28 days. 


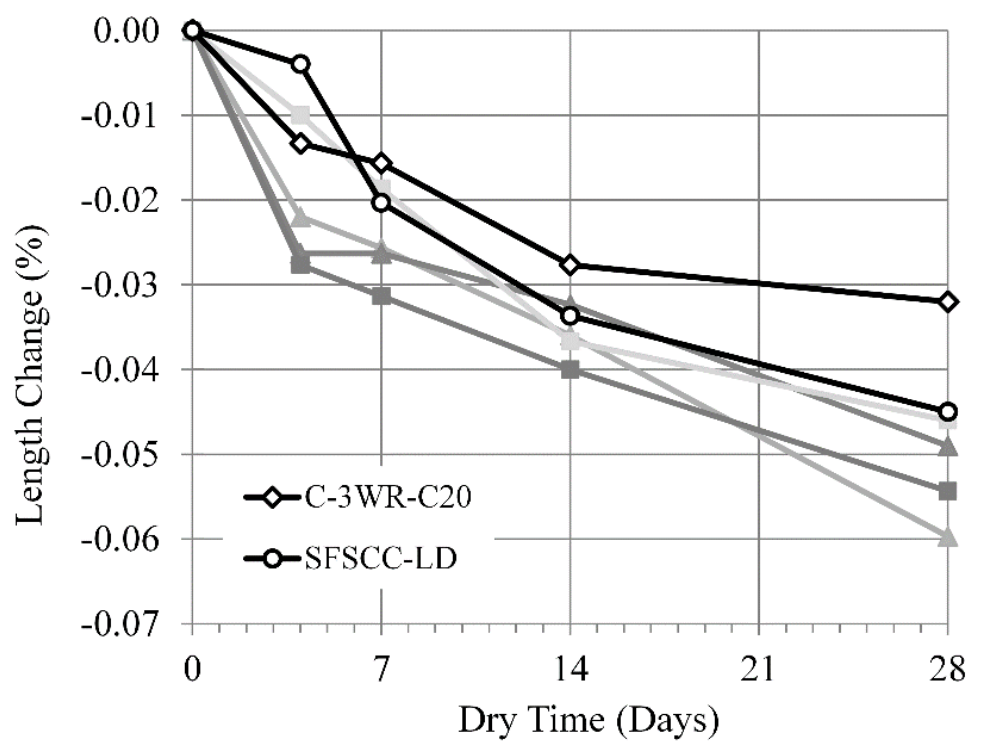

Fig. 9 Percent length change due to shrinkage of concrete prisms [39].

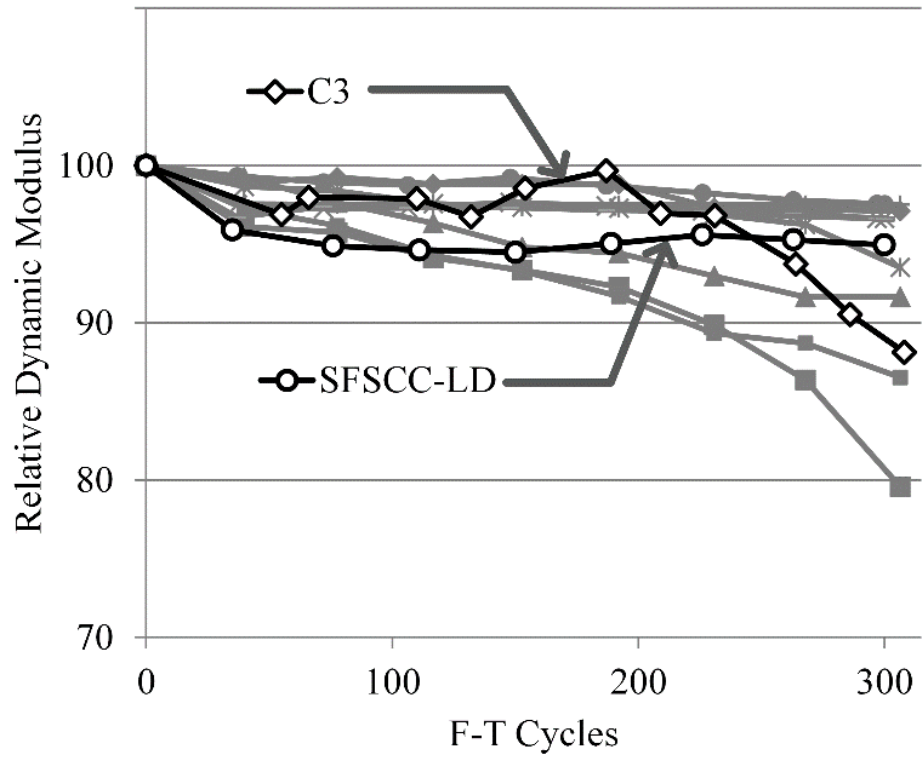

Fig. 10 Relative dynamic modulus of concrete with increasing freezing-thawing cycles.

Overall, SFSCC can be designed to incorporate limestone fines. The unique contribution of limestone fines to rheological properties by increasing viscosity may be offset by proper proportioning of other constituent materials so as not to adversely affect the flowability of concrete. On the other hand, limestone fines has been used in SCC to improve its stability to segregation [2]. SFSCC with limestone fines can also be design to achieve hardened concrete properties that are comparable to conventional concrete pavement.

\section{High Performance Concrete}

The development of HPC utilizing limestone fines was conceived to take advantage of the rapid setting behavior demonstrated by concrete with limestone fines and the particle packing concept in UHPC (ultra-high performance concrete). Such concrete has potential applications for rapid concrete repair. 


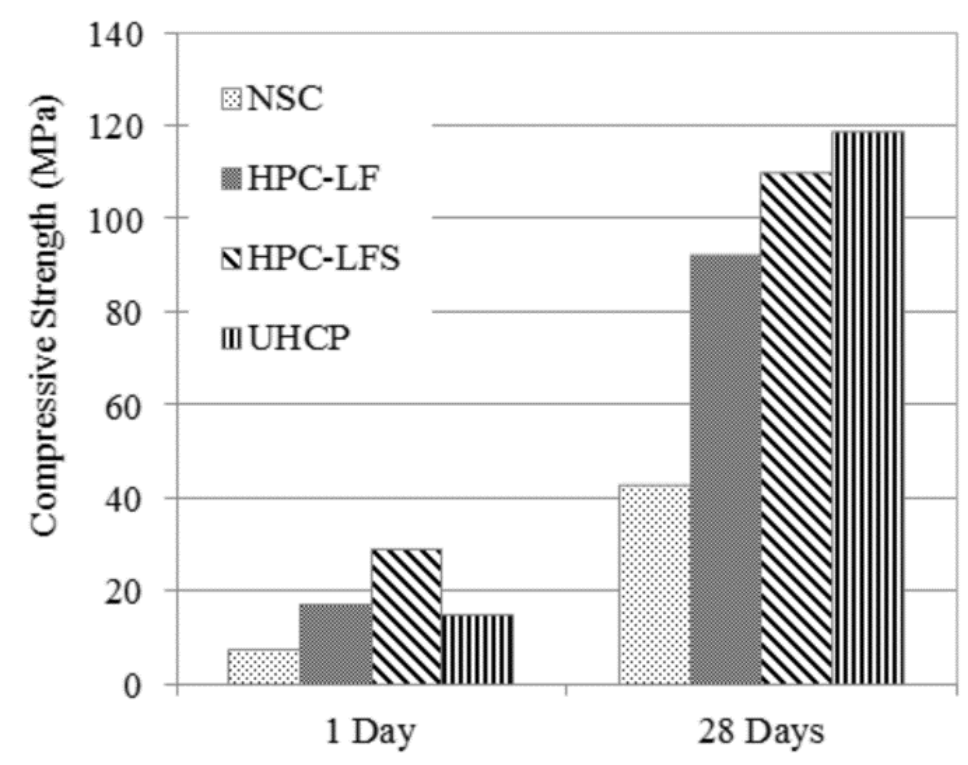

Fig. 11 Compressive strength of concrete at 1 day and 28 days.

Two mixtures of limestone fines-based HPC have been developed: the first only had limestone fines as aggregate, $50.7 \%$ by total mass of mixture (HPC-LF); and second had limestone fines and river sand, $25.4 \%$ equally by mass of mixture (HPC-LFS). The results show that the one-day compressive strength of HPC-LF reached 17.6 MPa, while HPC-LFS reached 29.4 MPa. At 28 days, the HPC-LF and HPC-LFS mixes had a strength value of 109.7 and $92.1 \mathrm{MPa}$, respectively. For comparison, UHPC that was not steam-treated [40] can have a lower compressive strength at 1 day, but eventually have higher later age strength as shown in Fig. 11. As a rapid concrete repair material, several key properties have to be investigated, such as flowability, rate of hydration, bond strength, shrinkage behavior, and freezing-thawing resistance. These are currently being studied.

\section{Conclusions}

Limestone fines used to replace Type IP cement slightly improved (e.g., $5 \%$ to $10 \%$ ) concrete compressive strength. However, the replacement for Type I cement decreased compressive strength. This is likely due to size of the limestone fines being complementary to the combination of cement and fly ash to improve packing on Type IP. In addition, there may be a chemical interaction between the fly ash in Type IP and limestone fines, which also facilitates concrete strength gain.

When limestone fines are used in SFSCC mix, proper proportioning of constituent materials is necessary to balance the increase in viscosity of mortar and to achieve desirable rheological properties of the SFSCC-LD. Limestone fines can be used in SFSCC as a partial cement replacement without adverse effects on strength and durability.

Limestone fines can be used as an aggregate/filler to develop high strength concrete with 1-day strength greater than $28 \mathrm{MPa}$. This will be suitable for applications such as rapid concrete repair. Key properties such as flowability, rate of hydration, bond strength, shrinkage behavior and freezing-thawing resistance are currently being studied.

\section{Acknowledgments}

The information on SFSCC is a part of a large project sponsored by Iowa, Kansas, Nebraska, New York and Washington State DOT (Departments of Transportation), the FHWA (Federal Highway Administration) and the $\mathrm{CP}$ Tech Center (National 
Center of Concrete Pavement Technology).The authors gratefully acknowledge the support.

\section{References}

[1] Willett, J. C. 2006. Minerals Yearbook: Stone, Crushed. Virginia: U.S. Geological Survey.

[2] Ramezanianpour, A. A., Ghiasvand, E., Nickseresht, I., Mahdikhani, M., and Moodi, F. 2009. "Influence of Various Amounts of Limestone Powder on Performance of Portland Limestone Cement Concretes." Cement and Concrete Composites 31 (10): 715-20.

[3] Yahia, A., Tanimura, M., and Shimoyama, Y. 2005. "Rheological Properties of Highly Flowable Mortar Containing Limestone Filler-Effect of Powder Content and W/C Ratio." Cement and Concrete Research 35 (3): 532-39.

[4] Bonavetti, V., Donza, H., Rahhal, V., and Irassar, E. F. 1999. "High Strength Concrete with Limestone Filler Cements." In High-Performance Concrete and Performance and Quality of Concrete Structures, edited by Malhotra, V. M., Helene, P., Prudencio Jr., L. R., and Dal Molin, D. C. C. Vol. 186. Farmington Hill: ACI Special Publication.

[5] Bonavetti, V., Donza, H. A., Menendez, G., Cabrera, O. A., and Irassar, E. F. 2003. "Limestone Filler Cement in Low W/C Concrete: A Rational Use of Energy." Cement and Concrete Research 33 (6): 865-71.

[6] Bentz, D. P., Sato, T., De la Varga, I., and Weiss, W. J. 2012. "Fine Limestone Additions to Regulate Setting in High Volume Fly Ash Mixtures." Cement and Concrete Composites 34 (1): 11-7.

[7] Péra, J., Husson, S., and Guilhot, B. 1999. "Influence of Finely Ground Limestone on Cement Hydration." Cement and Concrete Composites 21 (2): 99-105.

[8] Heikal, M., El-Didamony, H., and Morsy, M. S. 2000. "Limestone-Filled Pozzolanic Cement." Cement and Concrete Research 30 (11): 1827-34.

[9] Kakali, G., Tsivilis, S., Aggeli, E., and Bati, M. 2000. "Hydration Products of $\mathrm{C}_{3} \mathrm{~A}, \mathrm{C}_{3} \mathrm{~S}$ and Portland Cement in the Presence of $\mathrm{CaCO}_{3}$." Cement and Concrete Research 30 (7): 1073-7.

[10] Bonavetti, V. L., Rahhal, V. F., and Irassar, E. F. 2001. "Studies on the Carboaluminate Formation in Limestone Filler-Blended Cements." Cement and Concrete Research 31 (6): 853-9.

[11] Ghrici, M., Kenai, S., and Said-Mansour, M. 2007. "Mechanical Properties and Durability of Mortar and Concrete Containing Natural Pozzolana and Limestone Blended Cements." Cement and Concrete Composites 29 (7): 542-9.

[12] Le Saout, L. G., Gallucci, E., and Scrivener, K. 2008.
"Influence of Limestone on the Hydration of Portland Cements." Cement and Concrete Research 38 (6): 848-60.

[13] Vuk, T., Tinta, V., Gabrovsek, R., and Kaucic, V. 2001. "The Effects of Limestone Addition, Clinker Type and Fineness on Properties of Portland Cement." Cement and Concrete Research 31:135-9.

[14] De Weerdt, K., Kjellsen, K. O., Sellevold, E., and Justnes, H. 2011. "Synergy between Fly Ash and Limestone Powder in Ternary Cements." Cement and Concrete Composites 33 (1): 30-8.

[15] Pera, J., Husson, S., and Guilhot, B. 1999. "Influence of Finely Ground Limestone on Cement Hydration." Cement Concrete Composites 21:99-105.

[16] Cyr, M., Lawrence, P., and Ringot, E. 2006. "Efficiency of Mineral Admixtures in Mortars: Quantification of the Physical and Chemical Effects of Fine Admixtures in Relation with Compressive Strength." Cement and Concrete Research 36 (2): 264-77.

[17] Sersale, K. 1992. "Advances in Portland and Blended Cement." In Proceeding 9th International Congress of the Chemistry of Cement, 277-9.

[18] British Standards Institution. 2011. BS EN 197-1, Cement. Composition, Specifications and Conformity Criteria for Common Cements. London: British Standards Institution.

[19] ASTM (American Society for Testing and Materials). 2004. ASTM Annual Book of Standards. Vol. 04.01. West Conshohocken, PA: ASTM.

[20] Canadian Standards Association/National Standard of Canada. 2009. CAN/CSA-A23.1-09/A23.2-09, Concrete Materials and Methods of Concrete Construction/Test Methods and Standard Practices for Concrete. Mississauga: Canadian Standards Association/National Standard of Canada.

[21] Hawkins, P., Tennis, P., and Detwiler, R. 2003. The Use of Limestone in Portland Cement: A State-of-the-Art Review. Skokie, IL: Portland Cement Association.

[22] Bonavetti, V., Donza, H., Menendez, G., Cabrera, O., and Irassar, E. F. 2003. "Limestone Filler Cement in Low W/C Concrete: A Rational Use of Energy." Cement and Concrete Research 33:865-71.

[23] Bentz, D. P., and Conway, J. T. 2001. "Computer Modeling of the Replacement of 'Coarse' Cement Particles by Inert Fillers in Low W/C Ratio Concretes: Hydration and Strength." Cement and Concrete Research 31 (3): 503-6.

[24] Bentz, D. P. 2005. "Replacement of 'Coarse' Cement Particles by Inert Fillers in Low W/C Ratio Concretes II: Experimental Validation." Cement and Concrete Research 35 (1): 185-8.

[25] Irassar, E. F. 2009. "Sulfate Attack on Cementitious Materials Containing Limestone Filler-A Review." 
Cement and Concrete Research 39 (3): 241-54.

[26] Bensted, J. 1999. "Thaumasite—Background and Nature in Deterioration of Cements, Mortars and Concretes." Cement and Concrete Composites 21 (2): 117-21.

[27] Bensted, J. 2003. "Thaumasite-Direct, Woodfordite and Other Possible Formation Routes." Cement and Concrete Composites 25 (8): 873-7.

[28] Kohler, S., Heinz, D., and Urbonas, L. 2006. "Effect of Ettringite on Thaumasite Formation." Cement and Concrete Research 36 (4): 697-706.

[29] Poppe, A. M., and De Schutter, G. 2005. "Cement Hydration in the Presence of High Filler Contents." Cement and Concrete Research 35 (12): 2290-9.

[30] Bentz, D. P. 2006. "Modeling the Influence of Limestone Filler on Cement Hydration Using CEMHYD3D." Cement and Concrete Composites 28 (2): 124-9.

[31] Voglis, N., Kakali, G., Chaniotakis, E., and Tsivilis, S. 2005. "Portland-Limestone Cements. Their Properties and Hydration Compared to Those of Other Composite Cements." Cement and Concrete Composites 27 (2): 191-6.

[32] Tsivilis, S., Chaniotakis, E., Badogiannis, E., Pahoulas, G., and Ilias, A. 1999. "A Study on the Parameters Affecting the Properties of Portland Limestone Cements." Cement and Concrete Composites 21 (2): 107-16.

[33] Hooton, R. D., and Nokken, M., and Thomas, M. D. A. 2007. Portland Limestone Cement: State-of-the-Art Report and Gap Analysis for CSA A 3000. Cement Association of Canada, Report SN3053.

[34] Wang, K., Shah, S. P., White, D. J., Gray, J., Voigt, T., Gang, L., Hu, J., Halverson, C., and Pekmezci, B. Y.
2005. Self-consolidating Concrete-Applications for Slip-Form Paving: Phase I (Feasibility Study). Report No. TPF-5(098), Center for Portland Cement Concrete Pavement Technology.

[35] Wang, K., Shah, S. P., Grove, J., Taylor, P., Wiegand, P., and Steffes, R., et al. 2011. Self-consolidating Concrete-Applications for Slip-Form Paving: Phase II. Final report, National Concrete Pavement Technology Center, Iowa State University.

[36] Lomboy, G. R., Wang, K., Taylor, P., and Shah, S. P. 2012. "Guidelines for Design, Testing, Production and Construction of Semi-flowable SCC for Slip-Form Paving." International Journal of Pavement Engineering 13 (3): 216-25.

[37] Hu, J., and Wang, K. 2011. "Effect of Coarse Aggregate Characteristics on Concrete Rheology." Construction and Building Materials 25 (3): 1196-204.

[38] Wang, K., Shah, S. P., Breitenbuecher, R., and Lomboy, G. R. 2014. "Design, Properties, and Performance of Semi-flowable Self-consolidating Concrete-An Overview." In RILEM Proceedings on SCC 2014-3rd International Symposium on Design, Performance and Use of Self-consolidating Concrete, 4-12.

[39] Lomboy, G. R., Wang, K., and Ouyang, C. 2011. "Shrinkage and Fracture Properties of Semi-flowable Self-consolidating Concrete." ASCE Journal of Materials in Civil Engineering 23: 1514-24.

[40] Graybeal, B. A. 2007. "Compressive Behavior of Ultra-High-Performance Fiber-Reinforced Concrete." ACI Materials Journal 104 (2): 146-52. 